\title{
Recycling of environmentally problematic plant wastes generated from greenhouse tomato crops through vermicomposting
}

\author{
M. J. Fernández-Gómez • M. Díaz-Raviña • \\ E. Romero • R. Nogales
}

Received: 6 October 2011/Revised: 17 January 2012/ Accepted: 27 March 2012/Published online: 20 March 2013

(C) Islamic Azad University (IAU) 2013

\begin{abstract}
The enormous quantity of plant waste produced from greenhouse tomato crops is an environmental problem that should be solved by recycling that waste into valuable organic products through low-cost technologies, such as vermicomposting. Feasibility of vermicomposting greenhouse tomato-plant waste $(\mathrm{P})$ using paper-mill sludge (S) as complementary waste was investigated by this study. Earthworm development in P, S, and two mixtures of both wastes was monitored over 24 weeks and compared with that in cow dung (D), an optimum organic-waste to be vermicomposted. The effectiveness of vermicomposting to biostabilize those wastes was assessed by analysing phospholipid fatty acid composition, chemical features, plant-nutrient content, metal concentration, enzyme activities, and germination index (GI). A commercial vermicompost was also analyzed and taken as a reference of vermicompost quality. Earthworms did not survive in $\mathrm{P}$ alone, but a mixture of $\mathrm{P}$ with $\mathrm{S}$ at a ratio of $2: 1$ or $1: 1$ resulted in earthworm development similar to that observed in D. Phospholipid fatty acid analysis revealed that earthworm activity strongly transformed initial microbiota inhabiting the wastes, giving rise to vermicompost microbial communities which were similar to that of a
\end{abstract}

M. J. Fernández-Gómez $(\bowtie) \cdot$ E. Romero · R. Nogales Department of Environmental Protection, Estación Experimental del Zaidín (EEZ-CSIC), Profesor Albareda 1,

18008 Granada, Spain

e-mail: manuelj.fernandez.gomez@gmail.com

M. Díaz-Raviña

Department of Soil Biochemistry, Instituto de Investigaciones

Agrobiológicas de Galicia, Galicia, Spain commercial vermicompost. Both mixtures of $\mathrm{P}$ and $\mathrm{S}$ were properly biostabilized through vermicomposting, as indicated by decreases in their $\mathrm{C}: \mathrm{N}$ ratio and enzyme activities together with increases in their degree of maturity (GI $\sim 100 \%)$ after the process. This study demonstrates that the vermicomposting of tomato-plant waste together with paper-mill sludge allows the recycling of both wastes, thereby improving the environmental sustainability of greenhouse crops.

Keywords Biostabilization - Eisenia fetida earthworms . Enzyme activity - Microbial phospholipid fatty acids .

Paper-mill sludge

\section{Introduction}

Greenhouse crops are rapidly expanding in many countries because these agricultural systems are able to produce highvalue vegetables in great amounts all year. Although current statistical data on greenhouse crops at the world level are quite difficult to find, previous surveys reported that there are more than 2 million hectares of greenhouses in the world (Pardossi et al. 2004). Among greenhouse plants, tomato is the predominant crop (Alkoaik and Ghaly 2006). Despite that greenhouse tomatoes are agriculturally profitable, such intensive cultivation causes environmental impact due to the enormous volume of post-harvest refuse. Indeed, greenhouse tomato crops produce the greatest amount of plant waste, around 49 tonnes per greenhouse hectare and year, as compared to other greenhouse crops, which produce an average amount of $28.5 \mathrm{t} \mathrm{ha}^{-1}$ year $^{-1}$ (Manzano-Agugliaro 2007). Greenhouse plant wastes are often eliminated by dumping them in dry ravines or empty areas, originating uncontrolled burning, blocking of riverbeds, poisoning of cattle and sheep, 
and causing visual blight on the landscape (Parra et al. 2008). In addition, the disposal of greenhouse plant waste in landfills is an environmental problem as that waste is a potential source of methane, a gas which negatively contributes to global warming (Bicheldey and Latushkina 2010). Therefore, the annual production of plant waste from greenhouse crops poses a global environmental problem which requires urgent action.

The large quantity of plant waste produced from greenhouse crops should be considered an opportunity to generate energy or to produce valuable organic products. Given that the vegetable production in greenhouses requires abundant amounts of organic matter to renew the organic layer placed within greenhouse soil, the transformation of greenhouse plant waste into a valuable organicmaterial through low-cost technologies, such as composting or vermicomposting should be the preferred recycling method (Parra et al. 2008). Furthermore, the production of organic soil amendments through composting or vermicomposting of greenhouse plant waste should be a priority, taking into consideration that most southern European soils are degraded owing to a lack of organic matter (Zdruli et al. 2004). Nevertheless, greenhouse plant waste is hardly recycled into a stable organic material because this waste has features that hinder proper composting or vermicomposting, therefore producing unusable organic materials for agricultural practices or soil restoration.

Greenhouse plant wastes from diverse crops have features in common, such as high moisture, low $\mathrm{C} / \mathrm{N}$, and high portion of lignin fibres, which protect this waste from microbial attack, hindering composting processes. In the particular case of greenhouse tomato-plant waste, previous studies have concluded that waste has a bioavailable carbon content that is insufficient to develop a satisfactory thermophilic phase, which is necessary for its proper composting (Alkoaik and Ghaly 2005, 2006). The vermicomposting of greenhouse tomato-plant waste has also been reported to be unfeasible as that waste has concentrations of salts and ammonia that are lethal to earthworms (Fernández-Gómez et al. 2010). Consequently, to date, there are no studies which have successfully transformed greenhouse plant wastes into organic materials with agricultural value using composting or vermicomposting.

Several previous studies have reported that paper-mill sludge is also inadequate waste for earthworm development, although that waste can be successfully vermicomposted by preparing mixtures with another waste rich in nitrogen (Elvira et al. 1996, 1997; Kaur et al. 2010). Taking into consideration the physical structure and chemical composition of greenhouse tomato-plant waste and paper-mill sludge, both organic wastes could complement each other. Thus, mixing the two wastes can produce an organic substrate which may have a nutritive value for earthworms greater than that of each single waste. Moreover, tomato-plant waste could act as a bulking agent for the paper-mill sludge, improving the microclimatic condition of that waste and thus accelerating the simultaneous decomposition of both substances. In short, mixing the two wastes at a suitable ratio may result in an organic substrate which could be more suitably stabilized through vermicomposting than either waste alone. As a way of testing this hypothesis, the feasibility of vermicomposting greenhouse tomato-plant waste mixed with paper-mill sludge at two different ratios was investigated in this study. These wastes were produced in 2010, at the area of Motril (Granada, southern Spain), by intensive greenhouse tomato cultivation and by a paper-mill company. The earthworm species Eisenia fetida was used because this earthworm species is commonly used for vermicomposting in temperate climates and has recently been demonstrated to be useful in the vermicomposting of paper-mill sludge (Kaur et al. 2010). Consequently, an optimum waste to be biostabilized by using E. fetida (i.e. cow dung) was assayed as a vermicomposting control, as described by previous studies (Gupta and Garg 2009). The effectiveness of vermicomposting to biostabilize the different organic wastes was assessed by analysing their chemical features, enzyme activities, germination index (GI), and phospholipid fatty acids before and after vermicomposting. In addition, a commercial vermicompost produced from cattle manure using E. fetida was analyzed and taken as a reference of vermicompost quality for assessing the vermicomposts produced in this study.

\section{Materials and methods}

Earthworms and organic-waste collection

Non-clitellated earthworms (E. fetida) were selected from a culture bank at the Estación Experimental del Zaidín (CSIC), Granada (southern Spain). Tomato-plant waste (P) consisted of leaves, stems, and roots from whole tomato plants discarded from greenhouses after harvest. $\mathrm{P}$ was collected from an organic-waste-treatment installation for greenhouse wastes located in Motril (Granada, southern Spain) where they were being accumulated and air dried. Paper-mill sludge (S) was a secondary sludge (paper pulp) which was collected from the wastewatertreatment plant of Torraspapel S.A, a paper-mill company also located in Motril (Granada province, southern Spain). Cow dung (D), which was a mixture of feces and urine without any bedding material, was collected from a farmyard of dairy cows located in the city of Granada. 
A stable and mature commercial vermicompost $(\mathrm{CV})$ was purchased from Humus-Fertil Company (La Roda, Albacete, Spain). CV was produced from cattle manure which was processed in large-scale windrow system by using E. fetida.

\section{Experimental set-up}

$\mathrm{P}$ was chopped $(<1 \mathrm{~cm})$ and mixed with $\mathrm{S}$ at two ratios (dw:dw): a ratio of two to one (PS 2:1) and another ratio of one to one (PS 1:1). Three mixtures of $200 \mathrm{~g}$ ( $\mathrm{dw}$ ) each were separately made by mixing $\mathrm{P}$ and $\mathrm{S}$ at a $2: 1$ ratio. Similarly, three mixtures were made by mixing $\mathrm{P}$ and $S$ at a 1:1 ratio. Each single mixture was placed in a rectangular glass container $(15 \mathrm{~cm} \times 15 \mathrm{~cm} \times 5 \mathrm{~cm})$ and its moisture content was adjusted to $80 \%$ with water. After a 2-week period in which the mixtures were airdried $\left(20^{\circ} \mathrm{C}\right)$ to eliminate the volatile substances potentially toxic to earthworms, each organic substrate was remoisturized and placed inside a plastic circular pot (13 $\mathrm{cm}$ diameter $\times 12 \mathrm{~cm}$ high), which had a perforated bottom for aeration and drainage. Thus, three replicated vermibeds constituted of PS 2:1 and three of PS 1:1 were constructed. Another two types of vermibeds were constructed in triplicate as described above. One vermibed type made of $\mathrm{P}$ as the only material, and the other type constituted of $\mathrm{S}$ alone. In addition, three control vermibeds containing $200 \mathrm{~g}$ (dw) of cow dung (D) each were similarly built. A layer of partially vermicomposted material $(1 \mathrm{~cm})$, which was collected from the earthworm culture bank, was placed on the top surface of each vermibed and 25 non-clitellated earthworms, weighing $0.20 \mathrm{~g}$ each one were inoculated within. All vermibeds were kept in darkness at $20{ }^{\circ} \mathrm{C}$ for 24 weeks, maintaining their moisture around $80 \%$ by periodical watering. The earthworms were counted and weighed weekly during the vermicomposting period. At the end of the process, the earthworms were removed by hand. Vermibed substrates were sampled immediately before earthworm inoculation and also at the end of vermicomposting. Samples were homogenized and divided into two subsamples, one of which was dried and finely ground for chemical analyses and maturity test, and the other was stored at $-20{ }^{\circ} \mathrm{C}$ for enzyme activities and phospholipid fatty acid (PLFA) analyses.

\section{Chemical analyses}

The $\mathrm{pH}$ and electrical conductivity (EC) were measured in a 1:10 sample:water (dw:v) ratio using a $\mathrm{pH}$ meter and a conductivity meter, respectively. Total organic carbon (TOC) and total nitrogen (N) were determined with a $\mathrm{CN}$ analyzer. Water-soluble carbon (WSC) was extracted by mechanical shaking at $60{ }^{\circ} \mathrm{C}$ for $1 \mathrm{~h}$ with distilled water (1:10 sample:water; dw:v). Afterwards, $1 \mathrm{ml}$ of the extract was digested with $1 \mathrm{ml}$ of $1 \mathrm{~N} \mathrm{~K}_{2} \mathrm{Cr}_{2} \mathrm{O}_{7}$ and $2 \mathrm{ml}$ of $97 \%$ $\mathrm{H}_{2} \mathrm{SO}_{4}$ at $160{ }^{\circ} \mathrm{C}$ for $30 \mathrm{~min}$. Total $\mathrm{P}$ was measured using the ammonium vanadomolybdate method. Total $\mathrm{K}$ and $\mathrm{Na}$ were measured by flame photometry and total $\mathrm{Ca}, \mathrm{Mg}, \mathrm{Fe}$, $\mathrm{Mn}, \mathrm{Cu}$, and $\mathrm{Zn}$ were determined by atomic absorption spectrometry after digestion of the samples with $\mathrm{HNO}_{3}: \mathrm{HClO}_{4}$ (Williams 1984).

\section{Enzyme activity analyses}

Total enzyme activities were determined in each sample $(0.2 \mathrm{~g})$ in triplicate. Dehydrogenase activity was determined according to the method described by García et al. (1997). The $\beta$-glucosidase and acid phosphatase activities were determined by measuring the amount of $p$-nitrophenol (PNP) produced from 4-nitrophenyl- $\beta$-D glucanopyranoside (PNG) and 4-nitrophenyl phosphate (PNPP) according to the methods reported by Tabatabai (1982) and Tabatabai and Bremner (1969), respectively. Urea or $N$ - $\alpha$-benzoyl-L-argininamide was used as the substrate for determining urease or protease activities as described by Kandeler and Gerber (1988) and Bonmatí et al. (1998), respectively. The $\mathrm{NH}_{4}^{+}$produced by both types of enzymes was measured after extraction with $2 \mathrm{M} \mathrm{KCl}$ through a salicylate-nitroprusside colorimetric method (Kandeler and Gerber 1988).

\section{Germination index}

The germination index was determined in each sample per triplicate according to the method of Zucconi et al. (1981). Briefly, GI was estimated by using 10 cress seeds (Lepidium sativum) inside a Petri plate containing a $1 \mathrm{ml}$ of 1:10 sample:water (dw:v) solution. After incubation in darkness at $25{ }^{\circ} \mathrm{C}$ for $24 \mathrm{~h}$, the seed-germination percentage and radicle growth was determined.

\section{Phospholipid fatty acid analysis}

Phospholipid fatty acid analysis is a technique based on the precept that some PLFAs are considered to be absolute signature substances (biomarkers) for specific groups of organisms, which provides qualitative and quantitative information on viable microorganisms inhabiting complex samples, since PLFAs are quickly degraded upon microbial death (Marschner 2007). The concentration of PLFAs in each sample was determined as described by Fostergård et al. (1993). In brief, the lipids were extracted from $0.5 \mathrm{~g}$ of each sample with a chloroform:methanol:citrate buffer mixture 1:2:0.8 (v:v:v) and separated into neutral lipids, glycolipids, and phospholipids by using a pre-packed 
silicic acid column. Subsequently, the phospholipids were subjected to a mild alkaline methanolysis and the resulting fatty acid methyl esters were identified by gas chromatography (flame-ionization detector) according to their relative retention times of the fatty acids, using methyl nondecanoate (19:0) as an internal standard. The PLFAs were designated in terms of total number of carbon atoms and position of the double bonds $(\omega)$. Prefixes 'a', 'i', 'cy' and ' $\mathrm{Me}$ ' refer to anteiso, iso, cyclopropyl and methyl branching. As reported previously (Marschner 2007; Moore-Kucera and Dick 2008), the sum of i15:0, a15:0, i16:0, i17:0, and a17:0 was used to estimate the biomass of Gram-positive bacterial in each sample; the sum of

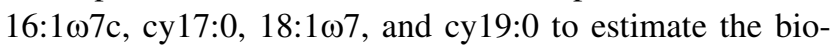
mass of Gram-negative bacteria; the sum of 10Me16:0, 10Me17:0, and 10Me18:0 to measure the biomass of actinomycetes; and the sum of a16:1w5, 18:1w9, and 18:2w6 to calculate the biomass of fungi. The sum of PLFA biomarkers for Gram-positive bacteria, Gram-negative bacteria, and actinomycetes, plus the fatty acids 14:0, 15:0, and 17:0 were taken as total biomass of all bacteria contained in a sample. Total viable microbial biomass was estimated as the sum of all the extracted PLFAs per gram of material (nmol PLFA g ${ }^{-1}$ ).

\section{Data analysis}

Repeated-measures ANOVA analyses were performed to evaluate the earthworm development over time in each vermicomposting process. A paired-sample Student's $t$ test was performed to assess differences in the parameters measured in each organic substrate before and after vermicomposting. In addition, a one-way ANOVA with post hoc mean separation based on Tukey's test was performed to assess the difference in the parameters analyzed in the organic wastes or in the resulting vermicompost. When concerning PLFA, statistical analyses were conducted using a normally distributed data set resulting from transforming PLFA concentrations $(\log (x i+1))$. Only a principal component analysis (PCA) was performed by using the untransformed PLFA date set. The statistical analyses were conducted at $>95 \%$ confidence level $(p<0.05)$ using the software SPSS ${ }^{\circledR} 13.0$ (Chicago, IL, USA).

\section{Results and discussion}

Earthworm development in the different vermibeds

All the earthworms placed in the vermibeds composed of $\mathrm{P}$ alone died after $24 \mathrm{~h}$. This could be due to the excessive salts concentration in that waste (Table 2). In organic wastes, salt concentrations exceeding $8 \mathrm{dS} \mathrm{m}^{-1}$ have been considered lethal for E. fetida (Edwards 1988). In line with this result, Fernández-Gómez et al. (2010) found that Eisenia andrei, an earthworm species closely related to E. fetida, died after $24 \mathrm{~h}$ when placed in a vermibed constituted of different greenhouse plant wastes due to the great salinity $\left(17 \mathrm{dS} \mathrm{m}^{-1}\right)$. Therefore, $\mathrm{P}$ cannot be vermicomposted as single waste by using E. fetida. The vermibeds made of $\mathrm{P}$ alone were therefore discarded since earthworm activity is compulsory for the successful stabilization of a wastes through vermicomposting (Domínguez et al. 2010). Previous studies have demonstrated that the degradation of organic wastes under mesophilic conditions without earthworms results in materials which are insufficiently degraded and mineralized when compared with vermicomposted materials (Atiyeh et al. 2000; Elvira et al. 1996; Kaur et al. 2010).

All earthworms were alive in the vermibeds composed of PS 2:1, PS 1:1, and S after $24 \mathrm{~h}$, indicating that those organic substrates were not lethal for $E$. fetida. Nevertheless, 39, 43, and $20 \%$ earthworm mortality occurred after 2 weeks in the vermicomposting of PS $2: 1$, PS $1: 1$, and $S$, respectively. However, those percentages of earthworm mortality did not significantly differ from that registered in control vermibeds after 2 weeks $(31 \%) \quad(F=1.53, p<0.28)$. To offset the possible earthworm death because of the stress caused by the initial earthworm handling, new juvenile earthworms $(0.20 \mathrm{~g})$ were carefully inoculated again at the 2nd week, reaching the same earthworm population (25) as at the beginning of the experiment. However, from the 2nd until the 10th week, significant declines in the earthworm populations $(F=281.78, p<0.05)$ were still observed in the vermicomposting of PS 2:1, PS 1:1, and $\mathrm{S}$, similar to the results for the vermicomposting of $\mathrm{D}$ $(F=1.78, p=0.23)$ (Fig. 1a). As the earthworm population decreased over time, all the surviving earthworms significantly gained weight $(F=28.02, p<0.05)$ (Fig. 1b). This suggests that the reduction in the earthworm population observed in all the vermibeds was due to high competition among earthworms inoculated during the earthworm-acclimation phase. At the 10th week of vermicomposting, the earthworms fed on PS 2:1 or PS 1:1 had mean weights that were 3.3- or 3.1-fold the initial value, while the mean weight of earthworm fed on D was 2.4-fold the initial weight. Earthworm fed on $\mathrm{S}$ alone had a mean weight which was 1.6-fold initial individual weight after 10 weeks. These results suggest that mixing $\mathrm{S}$ with $\mathrm{P}$ produces organic substrates which are more nutritious for E. fetida than $\mathrm{S}$ alone. From the 10th week to the end, significant differences were found in the earthworm populations over time in different 

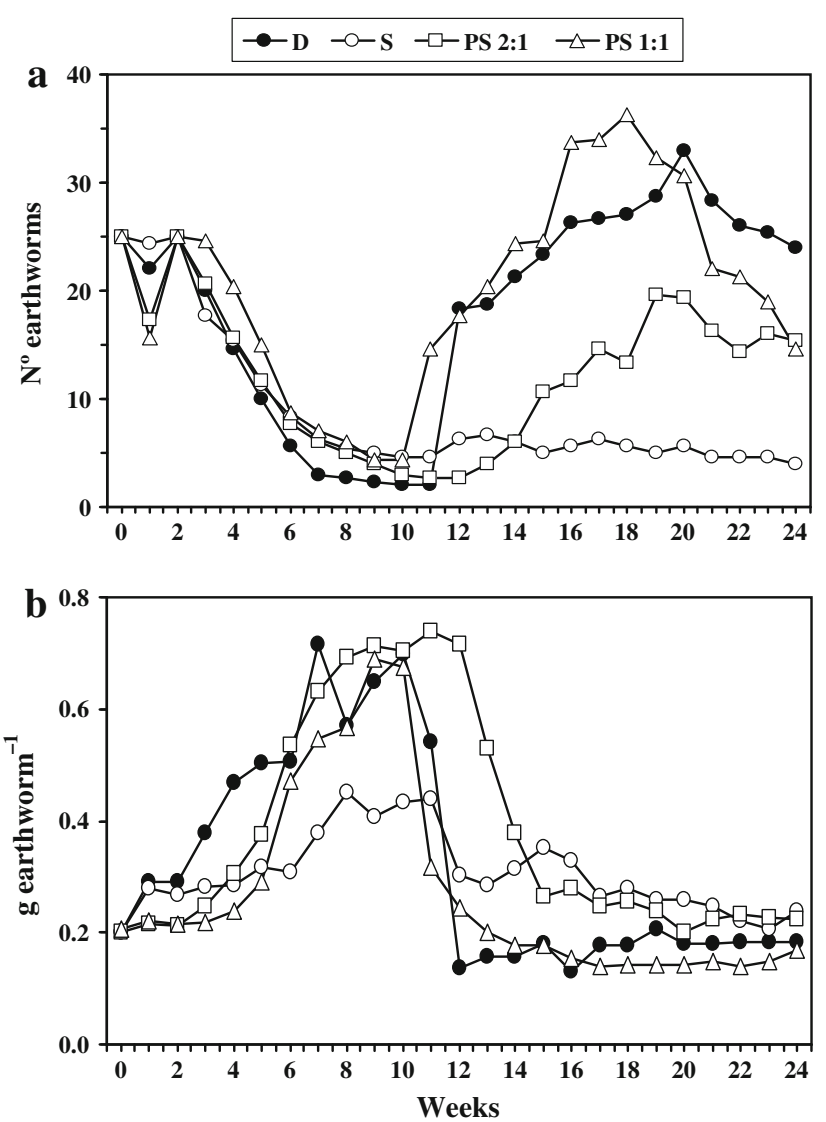

Fig. 1 Number (a) and mean earthworm weight (b) during the vermicomposting of cow dung (D, control), paper-mill sludge (S), and plant waste mixed with paper-mill sludge at a ratio of 2:1 (PS 2:1) or 1:1 (PS 1:1). Each symbol indicates the mean of three replicates

organic substrates (earthworm population: $F=2.90$, $p<0.05)$. During that period, the earthworm population rose in vermibeds composed of PS 2:1 or PS 1:1, showing growth curves resembling those of the control vermibeds (D). In contrast, the earthworm population observed in vermibeds composed of $\mathrm{S}$ did not increase in number over time. This was due to a low reproductive rate of the earthworms fed on $\mathrm{S}$, which produced a small number of new hatched earthworms as compared with that in the other vermibed types. Previous studies found lower earthworm reproduction during the vermicomposting of paper-mill sludge when compared with that in the vermicomposting of this waste mixed with sewage sludge (Elvira et al. 1997) or with cattle dung (Kaur et al. 2010), concluding that paper-mill sludge must be supplemented with other organic materials in order to achieve an adequate biostabilization by vermicomposting. Finally, the absence of a new increase in the mean earthworm weight suggests that the organic substrates had been completely degraded and more fresh material had to be added to maintain earthworm growth (Fig. 1b).

Assessment of waste transformation through PLFA analysis

Microbial biomass initially contained in all substrates, estimated as the sum of all the extracted PLFA per gram of material, decreased after the vermicomposting process (Table 1). More pronounced decreases were found in the substrates D and PS 1:1 whereas S and PS 2:1 showed nonsignificant decreases. This may be related to the comparatively better earthworm development in D and PS 1:1. Domínguez et al. (2010) stated that, in vermicomposting processes, earthworm activity depletes microbial biomass in organic substrates through selectively feeding on bacteria and fungi or indirectly consuming resources essentials for these microbial groups. Aira et al. (2006) reported that the sharp decrease in the microbial biomass after vermicomposting of pig slurry is a result of mineralization and stabilization of that waste. Notably, vermicomposting significantly reduced fungal PLFA in all the substrate types, perhaps because fungi cells are considered to be one of the main components of the earthworms' diet (Schönholzer et al. 1999). Thus, the inadequate earthworm development observed in earthworms fed on $\mathrm{S}$ could be partially attributed to its lower fungal biomass compared to that in the other organic substrates. In this sense, PLFA analysis could be useful for exploring organic wastes before vermicomposting in order to assess whether the wastes could be microbiologically adequate for earthworm growth.

The PCA was performed with the whole PLFA data set was useful to compare initial waste substrates and resulting vermicomposts according to their microbial community structure (Fig. 2). The distribution of samples on the plane defined by PC1 and PC2 (Fig. 2a), which explained $42 \%$ of the total variance, clearly separated the plant waste $(\mathrm{P})$ from the rest of initial substrates (lower values along PC2) and from the resulting vermicomposts (higher values along PC2). Likewise, a separation of the initial substrates from the resulting vermicomposts was shown by the plane defined by PC3 and PC4 (Fig. 2b), which explained $27 \%$ of the total variance. This PCA analysis indicated that: (1) microorganisms of greenhouse plant wastes differed greatly from those of the other samples, perhaps due to the lower $\mathrm{pH}$, higher TOC content, and $\mathrm{EC}$ recorded in $\mathrm{P}$ as compared with the other initial substrates and end vermicomposts; (2) microbial communities of different vermicomposts were grouped together, indicating that vermicomposting played a key role in shaping the microbial community structure in different substrates. In agreement with these results, Gómez-Brandón et al. (2010) reported that PLFA analysis is 


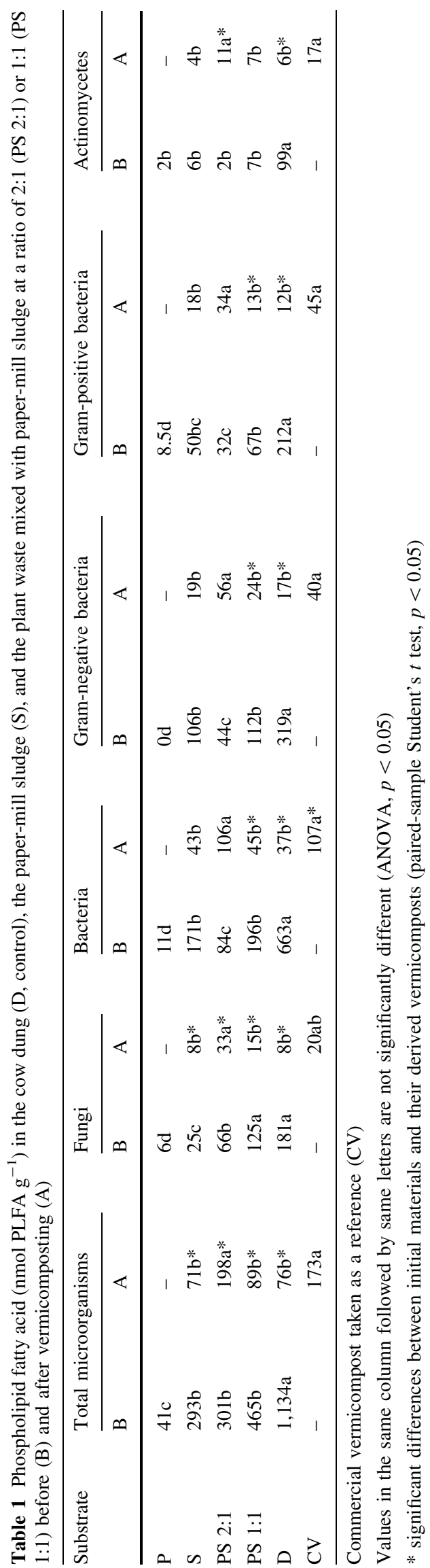

useful to discriminate waste stabilized by earthworms from unprocessed wastes.

The relative abundance of biomarker PLFAs for different microbial groups recorded in the vermicomposts produced in this study was compared with that of a commercial vermicompost (CV), which is considered stable, mature, and suitable for agricultural practices (Fig. 3). For all the vermicomposts produced (VD, VS, VPS 2:1, VPS 1:1), PLFA percentages for Gram-positive bacteria, Gram-negative bacteria, actinomycetes, and fungi relative to the total PLFA amount were in the range of $23-28,15-25,5-8$, and $10-17 \%$, respectively. These values were quite close to the relative abundance of these microbial groups registered in CV by PLFA analysis. However, a smaller percentage of Gram-negative bacteria and a greater percentage of fungi were observed in the vermicomposts produced from both mixtures of $\mathrm{P}$ and $\mathrm{S}$ (PS 2:1 and PS 1:1) compared to those in $\mathrm{CV}$. This suggests that $\mathrm{P}$ could boost the fungal growth in these vermibeds. These results are supported by Fernández-Gómez et al. (2010), who reported that earthworms greatly transformed different initial substrates into vermicomposts which were characterized by quite similar fingerprints to each other. These authors concluded that the dissimilarities found among those fingerprints can be attributed to the different chemical composition of each initial substrate vermicomposted.

Assessment of waste biostabilization through chemical analyses

After 24 weeks, the initial chemical properties of the different vermicomposting substrates varied depending on the wastes comprising the vermibeds (Table 2). The value of $\mathrm{pH}$ increased after vermicomposting only in the case of organic substrate which contained P. This may be a consequence of degrading organic acids contained in $\mathrm{P}$ during the vermicomposting of PS 2:1 and PS 1:1. The degradation of $\mathrm{P}$ mixed with $\mathrm{S}$ was reflected by significant decreases in the initial TOC of PS 2:1 (39\%) and PS 1:1 (34\%), whereas a non-significant reduction in TOC was observed after vermicomposting of $\mathrm{S}$, maybe because the TOC content in $\mathrm{S}$ was already low prior to vermicomposting. This indicates that a large fraction of organic-matter content in $\mathrm{P}$ was mineralized into $\mathrm{CO}_{2}$ or earthworm biomass during vermicomposting. In the case of vermicomposting control, a $29 \%$ decrease in the initial content in TOC of D was recorded. The degradation of the waste was also evidenced by decreases in WSC, which has been used as a indicator of the easily metabolized organic-matter fraction in organic wastes during vermicomposting (Benítez et al. 1999). Earthworms can directly break down organic waste and 


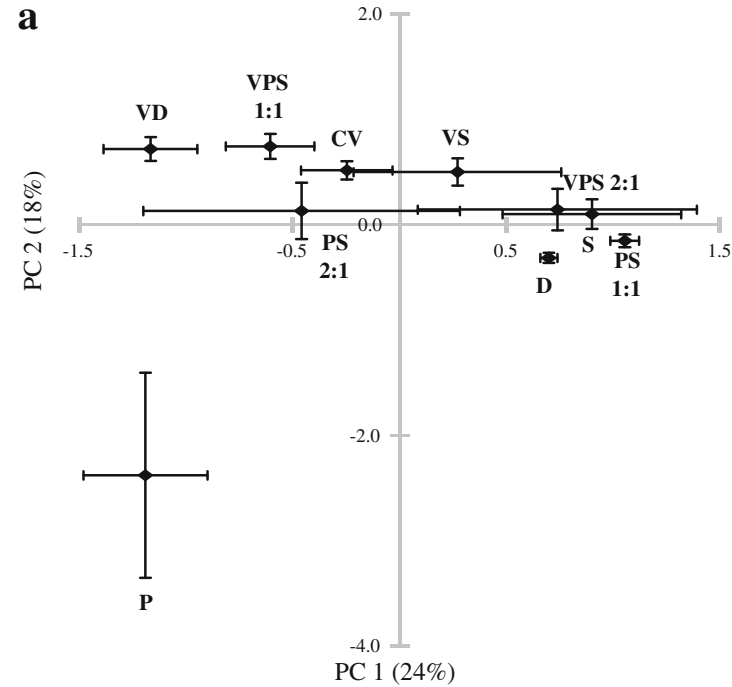

Fig. 2 Principal component analysis of PLFA contained in the initial materials (i.e. P, D, S, PS 2:1, and PS 1:1), their derived vermicomposts (i.e. VD, VS, VPS 2:1, and VPS 1:1) and in a

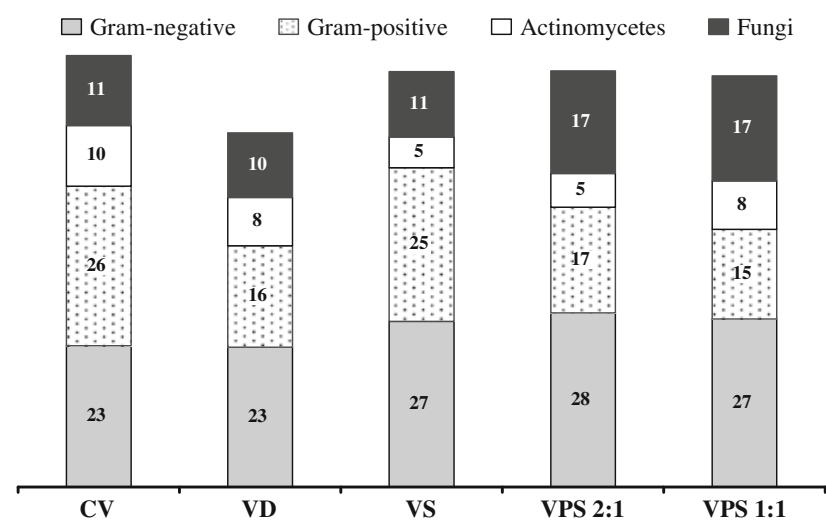

Fig. 3 Relative concentrations (\%) of PLFA in the vermicomposts produced in the present study (i.e. VD, VS, VPS 2:1, and VPS 1:1) and in a commercial vermicompost (i.e. CV). $D$ cow dung, $P$ plant wastes, $S$ paper-mill sludge

thus assimilate carbon from the more labile fractions of organic wastes (Edwards 1988). In addition, earthworms indirectly accelerate the mineralization of organic wastes by stimulating the development of degrading microorganisms during vermicomposting (Domínguez et al. 2010).

The consumption of organic compound by the earthworm and the microbiota involved in vermicomposting significantly lowered the $\mathrm{C}: \mathrm{N}$ ratio of all the organic substrates after vermicomposting. After vermicomposting, the percentage of reduction in the C:N ratio of PS 2:1, PS 1:1, or $\mathrm{S}$ was similar to that of $\mathrm{D}$. That ratio is currently used as an indicator of biostabilization of organic waste during

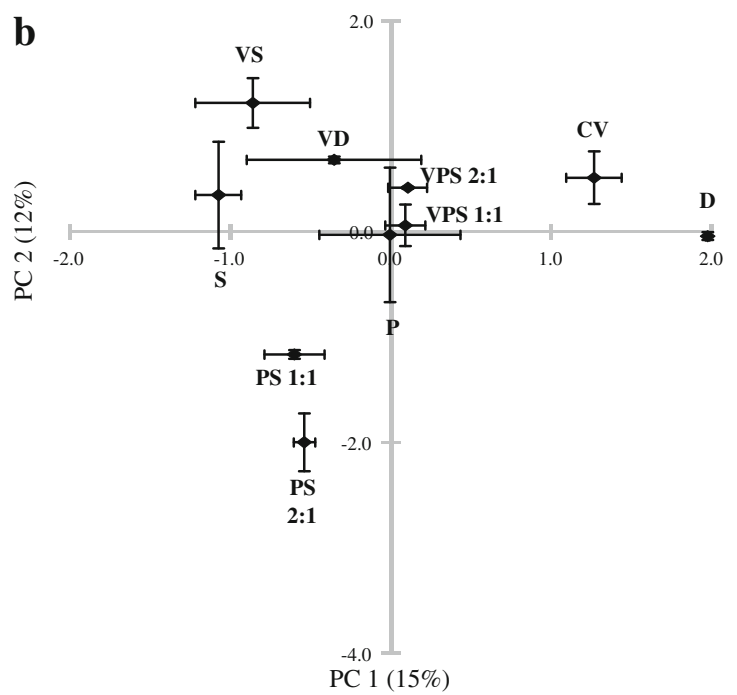

commercial vermicompost (i.e. CV). Error bars represent the mean standard error $(n=3)$. $D$ cow dung, $P$ plant wastes, $S$ paper-mill sludge

biological processes, since a significant reduction in the initial C:N ratio of an organic material has been commonly reported from early studies (Senesi 1989). On the other hand, the Spanish legislation for organic fertilizers obligate vermicomposts to register a $\mathrm{C}: \mathrm{N}$ ratio $<20$, since organic fertilizers which have a higher $\mathrm{C}: \mathrm{N}$ ratio may contain a great proportion of inorganic nutrients in unavailable forms to be uptake by plants because of adsorption of nutrients to organic C-compounds (Gobierno de España 2005). Like the commercial vermicompost (CV), all the vermicomposts produced by this study met this requirement. On the other hand, EC has been considered important to assess the quality of vermicompost. Although there are no mandatory limit values for EC in vermicomposts (Lasaridi et al. 2006), the suggested EC value is less than $1.5 \mathrm{dS} \mathrm{m}^{-1}$ for stabilized materials used as growing media, and less than $4 \mathrm{dS} \mathrm{m}^{-1}$, for organic soil amendments, as those values are tolerable by plants of medium salinity sensitivity. The initial salt content in the wastes was reduced by vermicomposting, when soluble elements were leached out by the excess of water applied. Thus, all the vermicomposts could be used as growing media or organic soil amendment according their EC values.

When concerning concentrations of elements considered to be essential for plant nutrition (i.e. N, P, and $\mathrm{K}$ ), the vermicomposts produced from PS 2:1 or PS 1:1 had NPK concentrations very similar to those of CV (Table 3), whereas the vermicompost from $\mathrm{S}$ had the lowest concentrations of those elements. This could be related to the inadequate earthworm development during the 
Table 3 Plant nutrients and heavy metals concentrations in the vermicomposts produced from paper-mill sludge (S), mixtures of plant waste and paper-mill sludge in 2:1 ratio (PS 2:1) or 1:1 ratio (PS 1:1), cow dung $(\mathrm{D}$, control)

\begin{tabular}{llllll}
\hline & $\mathrm{S}$ & PS 2:1 & PS 1:1 & $\mathrm{D}$ & $\mathrm{CV}$ \\
\hline $\mathrm{N}\left(\mathrm{g} \mathrm{kg}^{-1}\right)$ & $8.8 \mathrm{~b}$ & $12.4 \mathrm{a}$ & $11.6 \mathrm{a}$ & $11.9 \mathrm{a}$ & $19 \mathrm{a}$ \\
$\mathrm{P}\left(\mathrm{g} \mathrm{kg}^{-1}\right)$ & $1.7 \mathrm{c}$ & $4.4 \mathrm{a}$ & $4.3 \mathrm{a}$ & $2.9 \mathrm{bc}$ & $4.4 \mathrm{a}$ \\
$\mathrm{K}\left(\mathrm{g} \mathrm{kg}^{-1}\right)$ & $1.8 \mathrm{c}$ & $6.3 \mathrm{~b}$ & $5.3 \mathrm{~b}$ & $5.6 \mathrm{~b}$ & $14.8 \mathrm{a}$ \\
$\mathrm{Ca}\left(\mathrm{g} \mathrm{kg}^{-1}\right)$ & $131 \mathrm{ab}$ & $113 \mathrm{~b}$ & $146 \mathrm{a}$ & $52 \mathrm{~d}$ & $85 \mathrm{c}$ \\
$\mathrm{Mg}\left(\mathrm{g} \mathrm{kg}^{-1}\right)$ & $5 \mathrm{c}$ & $7 \mathrm{~b}$ & $8 \mathrm{~b}$ & $10 \mathrm{a}$ & $8 \mathrm{~b}$ \\
$\mathrm{Na}\left(\mathrm{mg} \mathrm{kg}^{-1}\right)$ & $330 \mathrm{~d}$ & $480 \mathrm{c}$ & $430 \mathrm{c}$ & $719 \mathrm{~b}$ & $1,868 \mathrm{a}$ \\
$\mathrm{Fe}\left(\mathrm{mg} \mathrm{kg}^{-1}\right)$ & $1,866 \mathrm{~d}$ & $2,114 \mathrm{c}$ & $2,100 \mathrm{c}$ & $6,015 \mathrm{a}$ & $3,228 \mathrm{~b}$ \\
$\mathrm{Mn}\left(\mathrm{mg} \mathrm{kg}^{-1}\right)$ & $57 \mathrm{~d}$ & $127 \mathrm{c}$ & $122 \mathrm{c}$ & $327 \mathrm{a}$ & $192 \mathrm{~b}$ \\
$\mathrm{Cu}\left(\mathrm{g} \mathrm{kg}^{-1}\right)$ & $23 \mathrm{~b}$ & $54 \mathrm{a}$ & $50 \mathrm{a}$ & $26 \mathrm{~b}$ & $43 \mathrm{a}$ \\
$\mathrm{Zn}\left(\mathrm{mg} \mathrm{kg}^{-1}\right)$ & $63 \mathrm{c}$ & $105 \mathrm{~b}$ & $108 \mathrm{~b}$ & $110 \mathrm{~b}$ & $153 \mathrm{a}$ \\
$\mathrm{Ni}\left(\mathrm{mg} \mathrm{kg}^{-1}\right)$ & $9 \mathrm{~b}$ & $9 \mathrm{~b}$ & $7 \mathrm{~b}$ & $43 \mathrm{a}$ & $8 \mathrm{~b}$ \\
$\mathrm{Cd}\left(\mathrm{mg} \mathrm{kg}^{-1}\right)$ & $<0.2 \mathrm{a}$ & $<0.2 \mathrm{a}$ & $<0.2 \mathrm{a}$ & $<0.2 \mathrm{a}$ & $<0.2 \mathrm{a}$ \\
$\mathrm{Pb}\left(\mathrm{mg} \mathrm{kg}^{-1}\right)$ & $<0.2 \mathrm{a}$ & $<0.2 \mathrm{a}$ & $<0.2 \mathrm{a}$ & $<0.2 \mathrm{a}$ & $<0.2 \mathrm{a}$ \\
\hline $\mathrm{Commeial}$ & & &
\end{tabular}

Commercial vermicompost taken as a reference $(\mathrm{CV})$

Values in the same row followed by same letters are not significantly different from each other (ANOVA, $p<0.05$ )

vermicomposting of $\mathrm{S}$ (Fig. 1). Previous studies have reported that earthworms can enrich the $\mathrm{N}$-content of waste by adding nitrogenous compound in the form of mucus and excretory substances or even as a consequence of decaying tissues from earthworms that die during the vermicomposting acclimation phase (Suthar and Singh 2008). Furthermore, $\mathrm{N}$ fixation by microorganisms which are stimulated by the earthworms have been reported during vermicomposting (Bhattacharya and Chattopadhyay 2004). The concentrations of other elements such as $\mathrm{Ca}, \mathrm{Mg}, \mathrm{Fe}$, or $\mathrm{Mn}$ differed from those of CV (Table 3). However, those elements are plant micronutrients so that the vermicomposts produced in the present study contained sufficient amounts of $\mathrm{Ca}, \mathrm{Mg}, \mathrm{Fe}$, and $\mathrm{Mn}$ for plant nutrition. Like $\mathrm{CV}$, all vermicompost produced in this study had total concentrations of heavy metals (i.e. $\mathrm{Cu}, \mathrm{Zn}, \mathrm{Ni}, \mathrm{Cd}$, and $\mathrm{Pb}$ ) that remained below the limit of heavy metals for organic fertilizers and soil amendments authorized by the Spanish legislation (Gobierno de España 2005).

Assessment of waste biostabilization by analysing enzyme activities

The dehydrogenase-activity values recorded initially in the organic substrates significantly declined after vermicomposting (Fig. 4a). During a vermicomposting process, a significant decrease in this activity in a waste is due to the mineralization of its organic matter that reduces available C substrates for microorganisms (Benítez et al. 1999). 

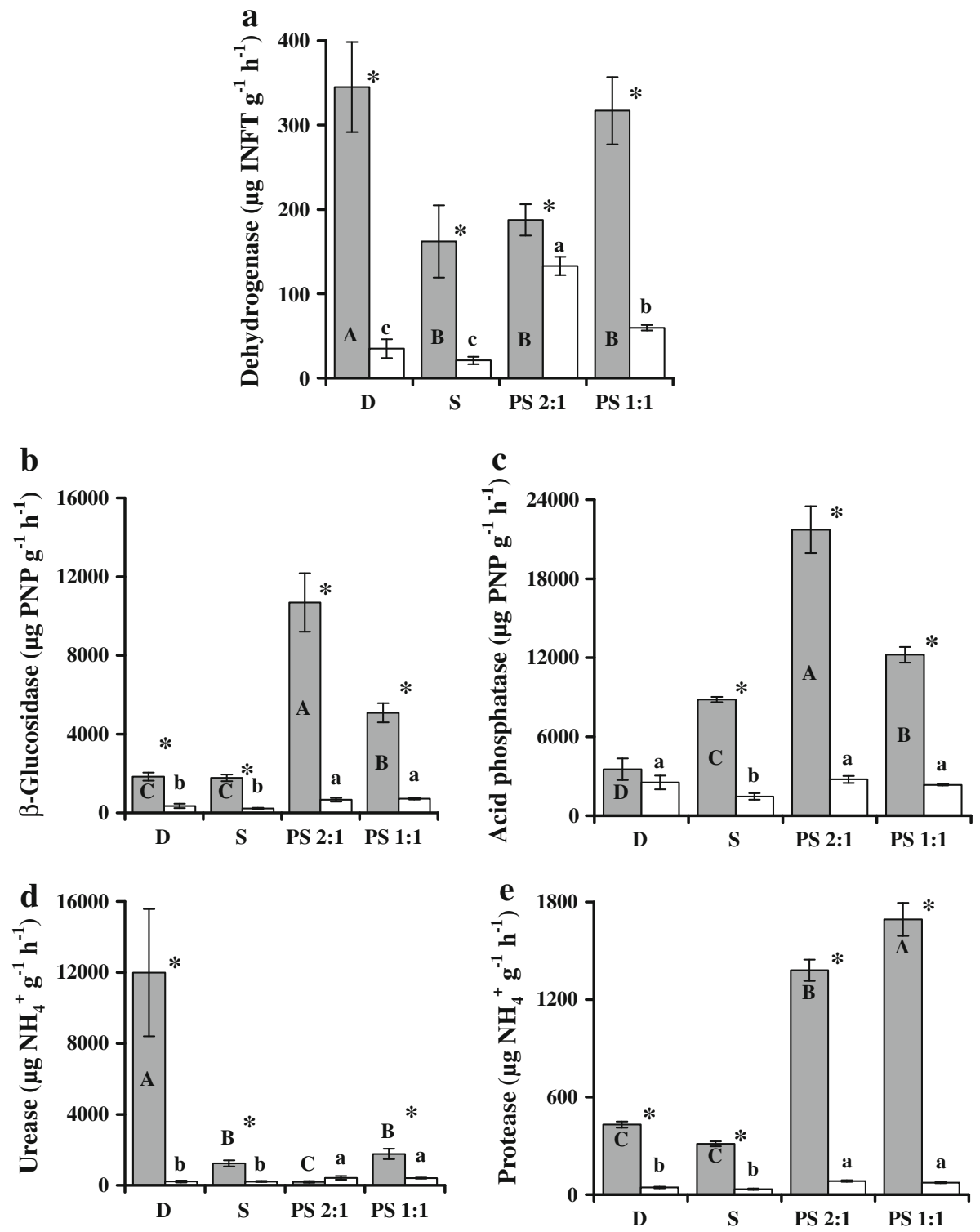

Fig. 4 Enzyme activities in the cow dung (D, control), the paper-mill sludge $(\mathrm{S})$, and the plant waste mixed with paper-mill sludge at a ratio of 2:1 (PS 2:1) or 1:1 (PS 1:1) before (dark bar) and after vermicomposting (pale bar). Error bars represent the mean standard error $(n=3)$. The asterisk denotes significant differences between

initial materials and their derived vermicomposts (paired-sample Student's $t$ test, $p<0.05$ ). Different capital letter and different lowercase indicate differences among initial substrates and vermicomposts, respectively (ANOVA, $p<0.05$ )

Dehydrogenases are intracellular enzymes involved in the respiratory chains of all active microorganisms, and thus the determination of dehydrogenase activity has commonly been used for estimating overall microbial activity in biotransformation processes, providing a clear indication of the dynamics of organic matter degradation (García et al. 1997). Among all the vermicompost produced, higher dehydrogenase activities were recorded in vermicomposts from PS 2:1 and PS 1:1. This suggests that the plant waste could maintain populations of degrading microorganisms of lignin fibres after the vermicomposting process.

As with dehydrogenase activity, $\beta$-glucosidases, which catalyse the hydrolysis of cellobiose and other disaccharides, registered lower activity in vermicomposted material than in initial substrates as a consequence of the mineralization of carbohydrates during vermicomposting (Fig. 4b). The great reduction in this enzyme activity in PS 2:1 as well as PS 1:1 after vermicomposting suggests that the large labile organic $\mathrm{C}$ fraction initially contained in plant wastes was degraded by the joint action of earthworms and microorganisms involved in the vermicomposting. 


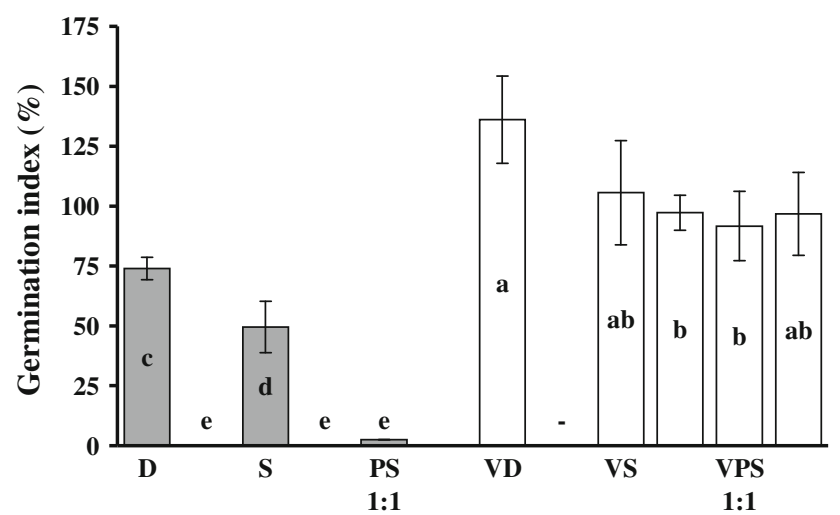

Fig. 5 Germination index in the cow dung (D, control), the papermill sludge (S), and the plant waste mixed with paper-mill sludge at a ratio of 2:1 (PS 2:1) or 1:1 (PS 1:1) before (dark bar) and after vermicomposting (pale bar). Error bars represent the mean standard error of three replicates. Materials with different lowercase letters are significantly different (ANOVA, $p<0.05$ )

Acid phosphatases, which catalyse the hydrolysis of organic phosphomonoester to an inorganic phosphate form, behaved in a way similar to that of $\beta$-glucosidases, although in the case of cow dung (D) the initial value of acid phosphatase did not significantly decline after vermicomposting (Fig. 4c). This could be because D had an initial $\mathrm{pH}$ value higher than that considered to be optimum for this type of enzyme (Table 2), between 4.0 and 6.5 according to Speir and Ross (1978).

Regarding the enzymes involved into the $\mathrm{N}$ mineralization, the activity of urease enzymes recorded in D before vermicomposting was greater than that in the others (Fig. 4d). This indicates a great amount of ureic compounds in D, which acted as enzyme-synthesisinducing substrate. However, as a consequence of the hydrolysis of those compounds during vermicomposting, this activity fell significantly after the vermicomposting of D. Protease activity also diminished in all the organic substrates after their vermicomposting, sharply falling after the vermicomposting of PS 2:1 and PS 1:1 (Fig. 4e). This sharp fall in protease suggests that earthworms and microorganisms together could be able first to depolymerise and afterwards to degrade the available peptides from the tomato-plant waste. Urease and protease activity values were significantly higher in vermicomposts PS 2:1 and PS 1:1 as compared with the other vermicomposts, suggesting that the level of these enzymes depends on the greater microbial activity in those vermicomposts as indicated by their higher dehydrogenase activity values (Fig. 4a); Benítez et al. (1999) found that both enzyme activities were closely correlated with dehydrogenase activity during the vermicomposting of sewage sludge.
In short, a significant fall in dehydrogenase activity together with decreases in hydrolytic activities are reportedly indicative of a significant decomposition and stabilization of organic wastes due to the joint action of earthworms and microorganisms during vermicomposting (Aira et al. 2006; Benítez et al. 1999).

Assessment of germination index as degree of maturity in initial substrate and resulting vermicomposts

Proper stabilization of wastes should allow their transformation into mature products, defined as a substrate which has no adverse effects on plants. The GI is one of the most widely used indices for determining the degree of maturity of organic fertilizers. GI values close to zero were initially recorded in P, PS 3:1, PS 2:1 and PS 1:1 (Fig. 5). This strong suppression of seed germination suggests that plant waste produced from greenhouse tomato crops is inadequate to be used as soil organic amendments because of its potential adverse effect on plants. According to Zucconi et al. (1981), only the organic substrate which registers a GI value higher than $60 \%$ can be considered to be safe and suitable for agricultural application. Low GI values initially found in organic substrates which contained $\mathrm{P}$ may be due to the high EC values of this waste (Table 2). Supporting this idea, previous studies designed to assess the features of a variety of composts and vermicomposts from different wastes found a large negative correlation between GI and EC (Campitelli and Ceppi 2008; Lasaridi et al. 2006). After vermicomposting, GI values of the different organic substrate increased significantly up to values around $100 \%$, or even greater in the case of cow dung. This denotes that all vermicomposted substrates had a great maturity, registering GI values which were similar to that of a commercial vermicompost, which is recommended as organic fertilizer for agriculture. These results point out that vermicomposting was capable of eliminating the adverse plant effects of unprocessed tomato-plant waste when this waste was processed together with paper-mill sludge.

\section{Conclusion}

A mixture of tomato-plant waste with paper-mill sludge at a ratio of $2: 1$ or 1:1 improved earthworm development during the vermicomposting of paper-mill sludge alone, and also allowed the vermicomposting of tomato-plant waste, which is otherwise harmful for $E$. fetida. The analysis of PLFA composition, chemical features, enzymatic activities, and GI indicated that the vermicomposting of mixtures of plant waste and paper-mill sludge 
improves the nutrient content, stability, and maturity of these waste mixtures. Our results also suggest that PLFA analysis provides complementary information that could be useful for selecting wastes for vermicomposting, assessing the process efficiency, and comparing different vermicomposts according to their microbial community structure.

Acknowledgments This study was financed by "Junta de Andalucía" project P05-AGR-00408. M. J. Fernández-Gómez thanks the Science and Innovation Ministry for their FPU doctoral grant (AP2006-03452). The authors also thank C. Cifuentes, A. Martín and J. Benitez for technical support and D. Nesbitt for assisting in the translation of the manuscript into English.

\section{References}

Aira M, Monroy F, Domínguez J (2006) Changes in microbial biomass and microbial activity of pig slurry after the transit through the gut of the earthworm Eudrilus eugeniae (Kinberg, 1867). Biol Fertil Soils 42(4):371-376

Alkoaik F, Ghaly AE (2005) Effect of inoculum size on the composting of greenhouse tomato plant trimmings. Compost Sci Util 13:262-273

Alkoaik F, Ghaly AE (2006) Influence of dairy manure addition on the biological and thermal kinetics of composting of greenhouse tomato plant residues. Waste Manage 26(8):902-913

Atiyeh RM, Domínguez J, Subler S, Edwards CA (2000) Changes in biochemical properties of cow manure during processing by earthworms (Eisenia andrei, Bouche) and the effects on seedling growth. Pedobiologia 44(6):709-724

Benítez E, Nogales R, Elvira C, Masciandaro G, Ceccanti B (1999) Enzyme activities as indicators of the stabilization of sewage sludges composting with Eisenia foetida. Bioresour Technol 67(3):297-303

Bhattacharya SS, Chattopadhyay GN (2004) Transformation of nitrogen during vermicomposting of fly ash. Waste Manage Res 22(6):488-491

Bicheldey TK, Latushkina EN (2010) Biogas emission prognosis at the landfills. Int J Environ Sci Technol 7(4):623-628

Bonmatí M, Ceccanti B, Nannipieri P (1998) Protease extraction from soil by sodium pyrophosphate and chemical characterization of the extracts. Soil Biol Biochem 30(14):2113-2125

Campitelli P, Ceppi S (2008) Chemical physical and biological compost and vermicompost characterization: a chemometric study. Chemometr Intell Lab 90(1):64-71

Domínguez J, Aira M, Gómez-Brandón M (2010) Vermicomposting: earthworms enhance the work of microbes. In: Insam H, FrankeWhittle I, Goberna M (eds) Microbes at work. Springer, Berlin

Edwards CA (1988) Breakdown of animal, vegetable and industrial organic wastes by earthworms. In: Edwards CA, Neuhauser EF (eds) Earthworms in waste and environmental management. SPB Academic Publishing BV, The Hague

Elvira C, Goicoechea M, Sampedro L, Mato S, Nogales R (1996) Bioconversion of solid paper-pulp mill sludge by earthworms. Bioresour Technol 57(2):173-177

Elvira C, Sampedro L, Domínguez J, Mato S (1997) Vermicomposting of wastewater sludge from paper-pulp industry with nitrogen rich materials. Soil Biol Biochem 29(3-4):759-762
Fernández-Gómez MJ, Romero E, Nogales R (2010) Feasibility of vermicomposting for vegetable greenhouse waste recycling. Bioresour Technol 101(24):9654-9660

Fostergård A, Bååth E, Tunlio A (1993) Shifts in the structure of soil microbial communities in limed forests as revealed by phospholipid fatty acid analysis. Soil Biol Biochem 25(6): 723-730

García C, Hernández T, Costa F (1997) Potential use of dehydrogenase activity as an index of microbial activity in degraded soils. Commun Soil Sci Plan 28(1-2):123-134

Gobierno de España (2005) Real Decreto 824/2005 sobre productos fertilizantes. BOE, Gobierno de España, Madrid

Gómez-Brandón M, Lazcano C, Lores M, Domínguez J (2010) Detritivorous earthworms modify microbial community structure and accelerate plant residue decomposition. Appl Soil Ecol 44(3):237-244

Gupta R, Garg VK (2009) Vermiremediation and nutrient recovery of non-recyclable paper waste employing Eisenia fetida. J Hazard Mater 162(1):430-439

Kandeler E, Gerber H (1988) Short-term assay of soil urease activity using colorimetric determination of ammonium. Biol Fertil Soils 6(1):68-72

Kaur A, Singh J, Vig AP, Dhaliwal SS, Rup PJ (2010) Cocomposting with and without Eisenia fetida for conversion of toxic paper mill sludge to a soil conditioner. Bioresour Technol 101(21):8192-8198

Lasaridi K, Protopapa I, Kotsou M, Pilidis G, Manios T, Kyriacou A (2006) Quality assessment of composts in the Greek market: the need for standards and quality assurance. J Environ Manage 80(1):58-65

Manzano-Agugliaro F (2007) Gasificación de residuos de invernadero para la obtención de energía eléctrica en el sur de España: ubicación mediante SIG. Interciencia 32(2):131136

Marschner P (2007) Soil microbial community structure and function assessed by FAME, PLFA and DGGE-Advantages and limitations. In: Varma A, Oelmüller R (eds) Advanced techniques in soil microbiology. Springer, Berlin

Moore-Kucera J, Dick RP (2008) PLFA profiling of microbial community structure and seasonal shifts in soils of a Douglas-fir chronosequence. Microb Ecol 55(3):500-511

Pardossi A, Tognoni F, Incrocci L (2004) Mediterranean greenhouse technology. Chron Hort 44:28-34

Parra S, Aguilar FJ, Calatrava J (2008) Decision modelling for environmental protection: the contingent valuation method applied to greenhouse waste management. Biosyst Eng 99(4):469-477

Schönholzer F, Hahn D, Zeyer J (1999) Origins and fate of fungi and bacteria in the gut of Lumbricus terrestris L. studied by image analysis. FEMS Microbiol Ecol 28(3):235-248

Senesi N (1989) Composted materials as organic fertilizers. Sci Total Environ 81-82(C):521-542

Speir TW, Ross DJ (1978) Soil phosphatase and sulphatase. In: Burns RG (ed) Soil enzymes. Academic Press, London

Suthar S, Singh S (2008) Vermicomposting of domestic waste by using two epigeic earthworms (Perionyx excavatus and Perionyx sansibaricus). Int J Environ Sci Technol 5(1):99-106

Tabatabai MA (1982) Soil enzymes. In: Page AL, Miller EM, Keeney DR (eds) Methods of Soil Analysis, Part 2, Chemical and Microbiological Properties. ASA and SSSA, Madison

Tabatabai MA, Bremner JM (1969) Use of $p$-nitrophenyl phosphate for assay of soil phosphatase activity. Soil Biol Biochem 1(4):301-307 
Williams S (1984) Official methods of analysis of the Association of Official Analytical Chemists 14th Ed. Association of Official Analytical Chemists, Arlington

Zdruli P, Jones RJA, Montanarella L (2004) Organic matter in the soils of southern Europe, European Soil Bureau Research
Report, EUR 21083 EN. Office for Official Publications of the European Communities, Luxembourg

Zucconi F, Forte M, Monaco A, De Bertoldi M (1981) Biological evaluation of compost maturity. BioCycle 22(4):27-29 